\title{
Transformation in Restriction-deficient Salmonella typhimurium LT2
}

\author{
By SIAO PING TSAI, RALPH J.HARTIN AND JUN-ICHI RYU* \\ Department of Microbiology, School of Medicine, Loma Linda University, Loma Linda, \\ CA 92350, USA
}

(Received 28 November 1988; revised 12 May 1989; accepted 24 May 1989)

\begin{abstract}
Stable restriction-deficient, modification-proficient galE (JR501) and F'galE+ (JR502) strains of Salmonella typhimurium were constructed and the effects of restriction on transformation by plasmid pBR322 were tested. Several factors which affect transformation efficiency were systematically examined to determine optimum transformation conditions and a simplified method is presented.
\end{abstract}

\section{INTRODUCTION}

Plasmid transformation is an established, routine step in gene cloning. Artificial transformation methods have been developed to induce competence in Escherichia coli (Mandel \& Higa, 1970; Cohen et al., 1972) and other bacteria (Saunders \& Saunders, 1987). These methods have been improved, either by using mutants such as $h s d R$ (Maniatis et al., 1982; Matsushima et al., 1987; Haima et al., 1987), $\operatorname{recBC}$ and $s b c A B$ (Oishi \& Irbe, 1977) in chromosomal transformation, or by introducing various physiological treatments (Oishi \& Irbe, 1977; Hanahan, 1983). Physiological conditions for optimum transformation efficiency vary, however, with the bacterial strain (Norgard et al., 1978; Dagert \& Ehrlich, 1979; Kushner, 1978) and type of DNA used for transformation (Oishi \& Irbe, 1977).

Salmonella typhimurium, like $E$. coli, does not undergo genetic transformation naturally. Lederberg \& Cohen (1974), however, reported successful transformation of a gal deletion mutant of $S$. typhimurium using the $\mathrm{CaCl}_{2}$ method developed for $E$. coli. Bursztyn et al. (1975) also successfully applied this $\mathrm{CaCl}_{2}$ method for $\mathrm{P} 22$ transfection of various rough mutants of $S$. typhimurium. Consequently, gal deletion and galE mutants have been favoured as recipients for transformation and transfection. More recently, MacLachlan \& Sanderson (1985) modified the method of Lederberg \& Cohen (1974) for transformation and examined plasmid transformation in many rough strains of $S$. typhimurium. Although galE and $r f a F$ mutants both showed relatively high transformation efficiencies, galE strains have been recommended since these mutants can readily be converted to a $\mathrm{P} 22$-sensitive $\mathrm{Gal}^{+}$phenotype.

$S$. typhimurium possess $h s d S A$, $h s d S B$, and $h s d L T$ (sometimes called $h s d L$ ) restrictionmodification genes (Colson \& Van Pel, 1974; Sanderson \& Hurley, 1987). Many plasmids originating from strains other than $S$. typhimurium undergo severe restriction when transformed into $S$. typhimurium. Bullas \& Ryu (1983) developed a mutant (LB5000) and a galE derivative (LB5010) of $S$. typhimurium which are $\mathrm{r}^{-} \mathrm{m}^{+}$for all three restriction-modification systems. These mutants proved to be good recipients when used in conjugation experiments with $E$. coli donors (Bullas \& Ryu, 1983), as well as being readily transformed (Mizuno et al., 1986). Plasmids isolated from these modification-proficient strains are fully modified and can be used to transform other $S$. typhimurium strains without encountering problems of restriction. Thus, these mutants are ideal mediators for genetic manipulation in $S$. typhimurium (Sanderson \& Stocker, 1987). During the course of this study the modification phenotype of the $h s d S A$ genes in both LB5000 and LB5010 was found to be unstable. A semiquantitative modification test (Bullas et al., 1980) using P3 phage showed that phages propagated on strains LB5000 and LB5010 were 
not modified for $h s d S A$, and thus were restricted by wild-type $S$. typhimurium. Hence, the modification phenotype has changed from $\mathrm{m}_{\mathrm{SA}}^{+}$to $\mathrm{m}_{\mathrm{SA}}^{-}$. Bacteria distributed to other laboratories also demonstrated this same unstable modification phenotype (B. Stocker, personal communication). The purpose of this project was to construct a stable $\mathrm{r}^{-} \mathrm{m}^{+}$strain of $S$. typhimurium and investigate the effects of restriction on plasmid transformation. In addition, several physiological conditions were examined in detail in order to simplify transformation methods in this strain.

\section{METHODS}

Bacterial and phage strains. All the bacterial strains used in this study are $S$. typhimurium LT2 derivatives (Table 1). Strain LT2 is the wild-type strain. Strains 4274 and 4419 are derived from 4247 and are thus isogenic. Phages P1, L, P22, and P3 were identical to those described by Bullas \& Colson (1975), and were propagated as indicated by those authors. Phage P22HTint (Davis et al., 1980) was also used in some of the detailed mapping experiments.

Bacterial culture conditions. LB medium (Davis et al., 1980) containing 1\%(w/v) D-glucose (L-broth) and SOB medium (Hanahan, 1983) were used for liquid culture. Agar ( $1.5 \%$, w/v) and antibiotics (ampicillin, $50 \mu \mathrm{g} \mathrm{ml}^{-1}$, or tetracycline, $20 \mu \mathrm{g} \mathrm{ml}^{-1}$ ) were added to L-broth to provide selective agar media.

Plasmid and plasmid isolation. The plasmid primarily used in this study was pBR322 (Bethesda Research Laboratories) which was isolated from $E$. coli $\mathrm{RR} 1\left(\mathrm{r}_{\mathrm{B}}^{-} \mathrm{m}_{\mathrm{B}}^{-}\right.$, Maniatis et al., 1982). In one experiment, pBR 322 was isolated and purified from transformed $S$. typhimurium JR501 using the method described in Davis et al. (1986). Other plasmids were extracted from $E$. coli $\mathbf{K}\left(\mathrm{m}_{\mathbf{K}}^{+}\right)$strains using the same method.

Original transformation procedure. Several transformation methods described for enteric bacteria (Hanahan, 1983; MacLachlan \& Sanderson, 1985; Merrick et al., 1987; Lederberg \& Cohen, 1974) were evaluated before the following protocol, based on the methods of Cohen et al. (1972) and Bursztyn et al. (1975), was developed. An overnight culture grown in L-broth was diluted $1 / 20$ in SOB medium and incubated at $37^{\circ} \mathrm{C}$ with aeration until an $\mathrm{OD}_{510}$ of 0.6 was reached. Then $50 \mathrm{ml}$ of the culture was chilled, and the cells were harvested by centrifugation and dispersed in $50 \mathrm{ml}$ cold $\left(4^{\circ} \mathrm{C}\right) 0.1 \mathrm{M}-\mathrm{MgCl}_{2}$ (magnesium wash). The cell pellet was then resuspended in $25 \mathrm{ml} 0.1 \mathrm{M}$ $\mathrm{CaCl}_{2}$ and kept on ice for $20 \mathrm{~min}$ (calcium pre-incubation), followed by centrifugation in the cold and resuspension in $5 \mathrm{ml}$ cold $0 \cdot 1 \mathrm{M}-\mathrm{CaCl}_{2}$. Small volumes $(0 \cdot 2 \mathrm{ml})$ of the competent cell suspension were placed in prechilled glass test tubes $(10 \mathrm{~cm} \times 13 \mathrm{~mm})$ or $1.5 \mathrm{ml}$ plastic micro-centrifuge tubes containing $10 \mathrm{ng}\left(1 \mathrm{mg} \mathrm{ml}^{-1}\right)$ plasmid DNA. The DNA-cell mixture was chilled on ice for another $20 \mathrm{~min}$ before being placed in a $42^{\circ} \mathrm{C}$ water bath for $2 \mathrm{~min}$. L-broth $(0.8 \mathrm{ml}$, ambient temperature) was then added to the DNA-cell mixture and the culture was incubated at $37^{\circ} \mathrm{C}$ for $1 \mathrm{~h}$ (post-incubation) without aeration. Finally $100 \mu \mathrm{l}$ volumes were spread on selective agar containing ampicillin $\left(50 \mu \mathrm{g} \mathrm{ml}^{-1}\right)$ unless otherwise stated, and the seeded agar was incubated at $37^{\circ} \mathrm{C}$ overnight. A fraction of the post-incubated culture was diluted as necessary and spread on L-agar (in triplicate) to obtain viable cell counts. Means of the number of transformants per plate were obtained from at least two plates for calculation of transformation efficiency (transformants per $\mu \mathrm{g}$ DNA; Hanahan, 1987). Under the conditions described, there was a positive, linear relationship between the number of ampicillin-resistant transformants $\mathrm{ml}^{-1}$ and the concentration of pBR322 DNA used per $0.2 \mathrm{ml}$ of competent cells, up to a concentration of $1 \mu \mathrm{g}$ DNA. All experiments in this study were repeated at least three times and the data presented are representative of the results.

Restriction and modification test. The semi-quantitative drop test described by Bullas et al. (1980) was used to characterize the $h s d S A, h s d S B$ and $h s d L T$ phenotypes of each $S$. typhimurium strain used. Efficiencies of plating of phages L, P3 and P22, each with proper modification, were obtained in order to determine the restriction and modification phenotypes of $h s d S A, h s d S B$ and $h s d L T$, respectively. Phage plates were incubated overnight at $30^{\circ} \mathrm{C}$, because of the temperature-sensitive restriction phenotype of $h s d S A$ and $h s d S B$ genes (Colson \& Van Pel, 1974).

Table 1. S. typhimurium strains

\begin{tabular}{|c|c|c|c|}
\hline Strain & \multicolumn{2}{|c|}{ Relevant phenotype and genotype } & Reference \\
\hline LT2 & $r_{L T}^{+} m_{L T}^{+} r_{S A}^{+} m_{S A}^{+} r_{S B}^{+} m_{S B}^{+}$ & $\mathrm{gal}^{+}$ & Sanderson \& Stocker (1987) \\
\hline LB5000 & $r_{L T}^{-} m_{L T}^{+} r_{S_{A}}^{-} m_{S A}^{+*} r_{S_{B}}^{-} m_{S B}^{+}$ & $\mathrm{gal}^{+}$ & Bullas \& Ryu (1983) \\
\hline 4247 & $\mathrm{r}_{\mathrm{LT}}^{+} \mathrm{m}_{\mathrm{LT} T}^{+} \mathrm{r}_{\mathrm{S} A}^{+} \mathrm{m}_{\mathrm{SA}}^{+} \mathrm{r}_{\mathrm{SB}}^{+} \mathrm{m}_{\mathrm{S} B}^{+}$ & $\mathrm{gal}^{+}$ & Bullas et al. (1980) \\
\hline 4274 & $r_{L T}^{-} m_{L T}^{+} r_{S A}^{+} m_{S A}^{+} r_{S B}^{+} m_{S B}^{+}$ & $\mathrm{gal}^{+}$ & Bullas \& Colson (1975) \\
\hline 4419 & $r_{L T}^{-} m_{L T}^{+} r_{S A}^{-} m_{S A}^{+} r_{S B}^{+} m_{S B}^{+}$ & $\mathrm{gal}^{+}$ & Bullas et al. (1980) \\
\hline SL3684 & $r_{L T}^{+} m_{L T}^{+} r_{S A}^{+} m_{S A}^{+} r_{S B}^{+} m_{S B}^{+}$ & galE & MacLachlan \& Sanderson (1985) \\
\hline JR501 & $r_{L T}^{-} m_{L T}^{+} r_{S A}^{-} m_{S A}^{+} r_{S B}^{-} m_{S B}^{+}$ & galE & This study \\
\hline JR502 & $\mathrm{r}_{\mathrm{LT} T}^{-} \mathrm{m}_{\mathrm{L} T}^{+} \mathrm{r}_{\mathrm{S}}^{-} \mathrm{m}_{\mathrm{S} A}^{+} \mathrm{r}_{\mathrm{SB}}^{-} \mathrm{m}_{\mathrm{S} B}^{+}$ & $\begin{array}{l}\text { galE } \\
\text { F'gal }^{\prime}\end{array}$ & This study \\
\hline
\end{tabular}

* Phenotype has been changed to $\mathrm{m}_{\overline{\mathrm{S}}}^{-}$. See text for details. 
RESULTS AND DISCUSSION

Construction of a stable $r^{-} m^{+}$strain

Two strategies were tried before a new stable $\mathrm{r}^{-} \mathrm{m}^{+}$strain of $S$. typhimurium was constructed. The initial approach was simply to replace the unstable $h s d S A$ genes of LB5000 with the stable $h s d S A$ genes of the parental strain, 4419. This was accomplished by P1 transduction of the 4419 hsd $S A$ genes $\left(\mathrm{r}_{\mathrm{SA}}^{-} \mathrm{m}_{\mathrm{SA}}^{+}\right)$into LB5000 using $\operatorname{Tn} 5(z j i-1072:: \operatorname{Tn} 5$, Fig. 1) as the selection marker. The modification phenotype of the $h s d S A$ genes of the resultant strain was also unstable and soon changed to $\mathrm{m}_{\mathrm{SA}}^{-}$. The reason for the instability is not known. However, LB5000 may have acquired an additional chromosomal mutation outside the hsd genes when the hsdSB121 mutation was introduced by nitrosoguanidine mutagenesis (Bullas \& Ryu, 1983). In the second attempt to construct a stable $\mathrm{r}^{-} \mathrm{m}^{+}$strain, the $h s d S B 121\left(\mathrm{r}_{\mathrm{SB}}^{-} \mathrm{m}_{\mathrm{SB}}^{+}\right)$mutation of LB5000 was transferred by $\mathrm{P} 1$ transduction to a galE derivative of the parental strain, 4419 , which already possessed the $\mathrm{r}_{\mathrm{SA}}^{-}$and $\mathrm{r}_{\mathrm{LT}}^{-}$phenotypes. In order to move the hsdSB121 mutation into the same strain, Tn 10 insertions close to deo genes, and hence close to $h s d S B$ (Sanderson \& Hurley, 1987), were selected from a random pool of Tn 10 chromosomal insertions (obtained from G. Ames, University of California - Berkeley, USA). The insertions were mapped using both P22 and P1 transduction (Fig. 1). One of the Tn 10 insertions $z j j-4021:: \operatorname{Tn} 10$, was used to transfer hsdSB121 of LB5000 into strain 4419. The resultant strain was designated JR500. To examine the restriction-modification phenotype of JR500, plasmid $\mathrm{F}^{\prime} \mathrm{gal}^{+}$was introduced from strain 4529 . Many Tn 10 insertions isolated in this region, however, showed a lower percentage of linkage with markers close to the $h s d$ genes than expected from the published genetic map (Sanderson \& Hurley, 1987). Therefore, it is possible that this region contains more genetic material than previously thought. A tetracycline-sensitive derivative was subsequently isolated from JR500 $\mathrm{F}^{\prime} \mathrm{gal}^{+}$on Bochner selective agar (Bochner et al., 1980) and was designated JR502. A derivative of JR502 which had lost $\mathrm{F}^{\prime}$ gal ${ }^{+}$spontaneously was found and was designated JR501.

\section{Effect of restriction and galE mutation}

Several hsd mutants and galE mutants of $S$. typhimurium were used to investigate both the extent of the restriction of pBR322 DNA during transformation and the improvement in transformation efficiency due to galE mutations (Table 2). With strain 4247, which is restriction-proficient for all three systems, no transformants were obtained when up to $1 \mu \mathrm{g}$ DNA was used. Mutant strain 4419 had a transformation efficiency equal to strain 4274 . This may simply be due to the absence of an SA recognition site on pBR322. Strain SL3684, a galE mutant, had a greater transformation efficiency than the wild-type, as reported earlier (MacLachlan \& Sanderson, 1985), but one which was significantly lower than those of the restriction-deficient mutants. The combination of restriction-deficient and galE mutations (JR501) resulted in the highest transformation efficiencies. These results demonstrate that restriction is a major barrier to the introduction of unmodified plasmid into $S$. typhimurium by transformation. Although the recognition sites for $h s d S A$ and $h s d L T$ are not known, two $h s d S B$ sites have been reported on pBR322 (Nagaraja et al., 1985), which is consistent with our results.

Plasmid pBR322 was then isolated from JR501. This plasmid isolate transformed wild-type LT2 without being restricted, although the same plasmid isolate transformed SL3684 with $10^{2}$ higher efficiency, probably due to the galE character. Culture temperature $\left(30,37\right.$ and $43^{\circ} \mathrm{C}$ tested) of JR501 containing pBR322 did not affect transformation of LT2 by modified plasmid DNA, despite the fact that the hsdSB modification system is reported to be temperature sensitive (Colson \& Van Pel, 1974). Except for JR501 having a consistently higher transformation efficiency than JR502, differences in the response of these strains to treatments in the transformation protocol were negligible. The following experiments were done to maximize transformation efficiency in strains JR501 and JR502 and to simplify the transformation protocol.

\section{Factors affecting transformation efficiency}

It has been reported that in certain strains of $E$. coli, competence is dependent upon the bacterial growth stage (Norgard et al., 1978). Development of competence in strain JR502 also 


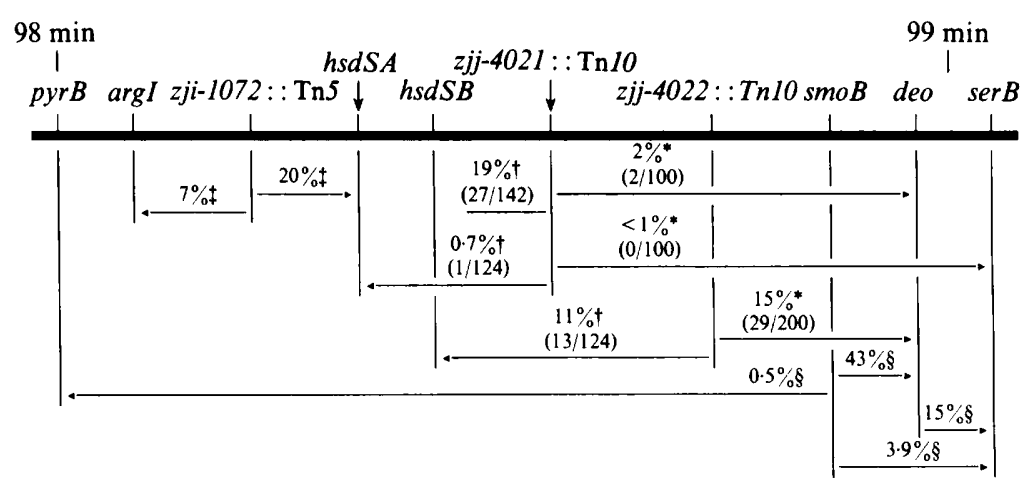

Fig. 1. Genetic map of the 98-99 minute region of $S$. typhimurium. Cotransduction frequencies are given in percentages and experimental data (in parentheses) from this study. The figure is not drawn to scale. *P22 transduction, this study; †P1 transduction, this study; $¥ P 22$ transduction, Sanderson \& Hurley (1987); §P1 transduction, Kozdroj \& Klopotowski (1979).

Table 2. Effect of restriction and galE mutation on transformation efficiency of $S$. typhimurium strains

Cells were harvested at $\mathrm{OD}_{510} 0 \cdot 2$.

\begin{tabular}{|c|c|c|c|c|c|}
\hline \multirow[b]{2}{*}{ Strain } & \multicolumn{3}{|c|}{ Restriction phenotype } & \multirow[b]{2}{*}{ gal } & \multirow{2}{*}{$\begin{array}{l}\text { Amp }_{\mathrm{r}} \text { transformation } \\
\text { efficiency* }\end{array}$} \\
\hline & SA & SB & LT & & \\
\hline JR501 & - & - & - & - & $1.4 \times 10^{6} \pm 44 \%$ \\
\hline JR502 & - & - & - & + & $2.6 \times 10^{5} \pm 22 \%$ \\
\hline SL3684 & + & + & + & - & $8.8 \times 10^{1} \pm 64 \%$ \\
\hline 4419 & - & + & - & + & $2.2 \times 10^{2} \pm 64 \%$ \\
\hline 4274 & + & + & - & + & $2.4 \times 10^{2} \pm 58 \%$ \\
\hline 4247 & + & + & + & + & 0 \\
\hline
\end{tabular}

demonstrated a dependency on growth stage. Optimum transformation efficiency was observed at an $\mathrm{OD}_{510}$ of $0 \cdot 2$ (about $1 \times 10^{8}$ cells $\mathrm{ml}^{-1}$ ) after approximately $1 \mathrm{~h}$ of growth. The difference in transformation efficiencies between the optimum point of the growth cycle and the stationary stage was more than two orders of magnitude.

$\mathrm{Mg}^{2+}$ ions stimulate transformation in many E. coli strains (Hanahan, 1987). However, the presence of $\mathrm{Mg}^{2+}$ in either the medium or the cell washing buffer, or in both, failed to improve transformation in $\mathrm{JR} 502$. In fact, $\mathrm{MgCl}_{2}(100 \mathrm{mM})$ incorporated into the wash reduced the transformation efficiency by approximately $15-70 \%$. The primary difference between SOB and L-broth medium is the supplemental $\mathrm{Mg}^{2+}$, in the form of $\mathrm{MgCl}_{2}$ and $\mathrm{MgSO}_{4}$, contained in SOB medium. Differences in the transformation efficiencies of cells grown in these media are thus negligible.

Among the cations tested $\left(\mathrm{Ca}^{2+}, \mathrm{Mn}^{2+}, \mathrm{Sr}^{2+}, \mathrm{Ba}^{2+}, \mathrm{Mg}^{2+}, \mathrm{Na}^{+}\right.$and $\left.\mathrm{Rb}^{+},\right), \mathrm{Ca}^{2+}$ gave the highest transformation efficiency in the $100-200 \mathrm{mM}$ range. More than $300 \mathrm{mM}-\mathrm{Ca}^{2+}$ decreased the viable cell count. The $\mathrm{Ca}^{2+}$ treatment was most effective in improving transformation efficiency at the cell-DNA mixture (calcium pre-incubation) stage in our original transformation protocol.

After treatment of cells with $\mathrm{Ca}^{2+}$ to promote competence, cell-DNA mixtures were heatshocked for various times at $42^{\circ} \mathrm{C}$, and the transformation efficiencies were calculated (Fig. 2). 


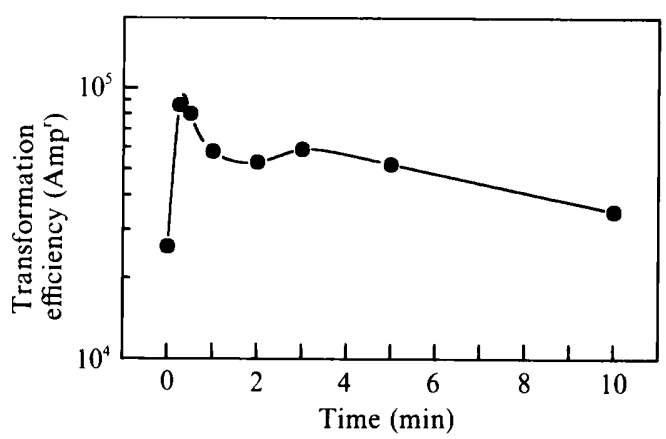

Fig. 2

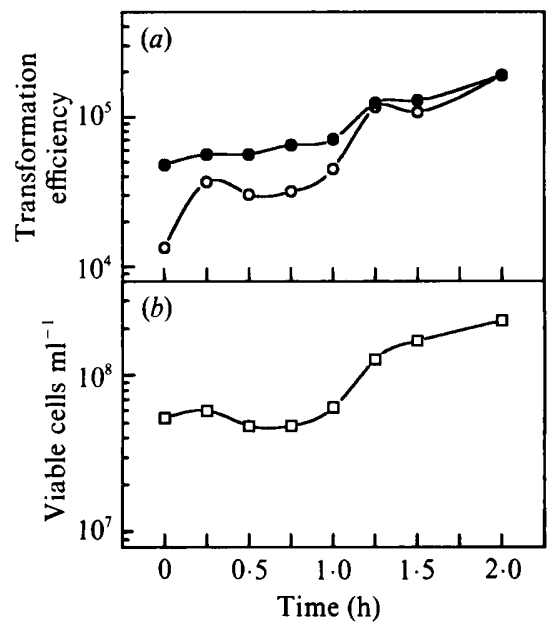

Fig. 3

Fig. 2. Effects of heat shock at $42{ }^{\circ} \mathrm{C}$ in transformation efficiency of JR501. Cells were treated with $\mathrm{CaCl}_{2}$ and mixed with pBR322 as described in Methods. Samples (in glass test tubes) were placed in a $42{ }^{\circ} \mathrm{C}$ water bath for various times.

Fig. 3. (a) Expression of ampicillin ( $\bullet$ ) and tetracycline $(O)$ resistance, and $(b)$ viable cell count of strain JR501. After the heat-shock treatment, cells were suspended in L-broth, and antibiotic-resistant transformants and viable cells were counted at various times.

Optimum transformation efficiency was obtained with a 15-30 s heat shock. Longer heat-shock treatments significantly reduced transformation efficiency. Similar results were obtained whether glass test tubes or plastic microcentrifuge tubes were used for this treatment. Heat shock at $37^{\circ} \mathrm{C}$ resulted in a similar curve, but transformation efficiency was slightly lower than at $42{ }^{\circ} \mathrm{C}$.

To determine the optimum time for post-incubation of JR501 with pBR322, heat-shocked cells were incubated in L-broth for up to $2 \mathrm{~h}$. Representative transformation efficiencies are shown in Fig. 3(a). Substantial numbers of ampicillin- and tetracycline-resistant transformants were recovered without post-incubation. When ampicillin resistance was used as the selective marker, no increase in the number of transformants was observed after $1 \mathrm{~h}$ post-incubation, although a slight increase of transformants (15\%) was observed in some experiments after 15-30 min post-incubation. Fewer transformants were obtained when tetracycline resistance was used as the selective marker, unless post-incubation times were more than $1 \mathrm{~h}$. Thus, post-incubation contributed to an increase in the number of tetracycline-resistant transformants. Increases in transformation efficiency after $1 \mathrm{~h}$, however, appeared to be due to onset of cell division, since viable cells began to increase after this time (Fig. $3 b$ ).

\section{Simplified transformation method}

Those treatments which had a negligible effect on transformation efficiency have been deleted from the original protocol to simplify the method. Accordingly, L-broth is recommended for both overnight and exponential-phase bacterial cultures. The magnesium wash, and calcium pre-incubation steps have been deleted. The heat-shock time has been reduced from $2 \mathrm{~min}$ to $30 \mathrm{~s}$, and incubation for expression of ampicillin resistance has been eliminated. The simplified transformation protocol is described below.

Grow $10 \mathrm{ml}$ S. typhimurium at $37^{\circ} \mathrm{C}$ in L-broth with shaking to $\mathrm{OD}_{510} 0 \cdot 2\left(1 \times 10^{8}\right.$ cells ml$\left.^{-1}\right)$. Centrifuge cells at 5000 r.p.m. for $10 \mathrm{~min}$ at $4{ }^{\circ} \mathrm{C}$, and resuspend them in $0.4 \mathrm{ml}$ cold $\left(4^{\circ} \mathrm{C}\right) 0.1 \mathrm{M}$ $\mathrm{CaCl}_{2}$. Dispense $0 \cdot 2 \mathrm{ml}$ of competent cells and mix with plasmid DNA (10-100 $\mathrm{ng}$ ). Chill the mixture for $20 \mathrm{~min}$ at $4{ }^{\circ} \mathrm{C}$. Heat-shock the mixture of cells and DNA for $30 \mathrm{~s}$ in a $42{ }^{\circ} \mathrm{C}$ water 
bath. Add $0.8 \mathrm{ml} \mathrm{L}$-broth (incubate the mixture for $30 \mathrm{~min}$ if tetracycline is used as a selection marker) and plate $0.1 \mathrm{ml}$ cells on L-agar containing antibiotics. Incubate at $37^{\circ} \mathrm{C}$ overnight.

When this shortened methodology was used with JR501, reasonable transformation efficiencies $\left(10^{5}-10^{6}\right)$ were consistently obtained using pBR322 and other plasmids such as pGEM $^{\mathrm{TM}}$-3Z (Promega), pBluescript ${ }^{\mathrm{TM}}$ (Stratagene), both with and without chromosomal inserts, and having a range of total DNA from $2 \cdot 8$ to $20 \mathrm{~kb}$.

The contribution of Elizabeth Hoag in isolating $\operatorname{Tn} 10$ insertions was greatly appreciated.

\section{REFERENCES}

Bochner, B., HuANG, G., Schieven, G. L. \& Ames, B. N. (1980). Positive selection for loss of tetracycline resistance. Journal of Bacteriology 143, 926-933.

Bullas, L. R. \& Colson, C. (1975). DNA restriction and modification systems in Salmonella. III. SP, a Salmonella potsdam system allelic to the SB system in Salmonella typhimurium. Molecular and General Genetics 139, 177-188.

Bullas, L. R. \& RYU, J. (1983). Salmonella typhimurium LT2 strains which are $\mathbf{r}^{-} \mathbf{m}^{+}$for all three chromosomally located systems of DNA restriction and modification. Journal of Bacteriology 156, 471-474.

Bullas, L. R., Colson, C. \& Neufeld, B. (1980). Deoxyribonucleic acid restriction and modification systems in Salmonella: chromosomally located systems of different serotypes. Journal of Bacteriology 141, 275-292.

Bursztyn, H., Sgaramella, V., Cifferri, O. \& LEDERBERG, J. (1975). Transfectability of rough strains of Salmonella typhimurium. Journal of Bacteriology 124, 1630-1634.

Cohen, S. N., Chang, A. C. Y. \& Hsu, L. (1972). Nonchromosomal antibiotic resistance in bacteria: genetic transformation of Escherichia coli by R-factor DNA. Proceedings of the National Academy of Sciences of the United States of America 69, 21102114.

Colson, C. \& VAN Pel, A. (1974). DNA restriction and modification systems in Salmonella. I. SA and SB, two Salmonella typhimurium systems determined by genes with a chromosomal location comparable to that of the Escherichia coli hsd genes. Molecular and General Genetics 129, 325-337.

Dagert, M. \& Ehrlich, S. D. (1979). Prolonged incubation in calcium chloride improves the competence of Escherichia coli cells. Gene 6, 23-28.

Davis, L. G., Dibner, M. D. \& BAtTey, J. F. (1986). Basic Methods in Molecular Biology, pp. 89-104. New York: Elsevier.

Davis, R. W., Botstein, D. \& Roth, J. R. (1980). Advanced Bacterial Genetics. Cold Spring Harbor, NY: Cold Spring Harbor Laboratory.

Haima, P., Bron, S. \& Venema, G. (1987). The effect of restriction on shotgun cloning and plasmid stability in Bacillus subtilis Marburg. Molecular and General Genetics 209, 335-342.

HANAHAN, D. (1983). Studies of transformation of Escherichia coli with plasmids. Journal of Molecular Biology 166, 557-580.

HaNAHAN, D. (1987). Mechanism of DNA transformation. In Escherichia coli and Salmonella typhimurium:
Cellular and Molecular Biology, vol. 2, pp. 1177-1183. Edited by C. F. Neidhardt and others. Washington, DC: American Society for Microbiology.

KozDROJ, H. \& KLOPOTOWSKI, T. (1979). The $s m o B$ mutation suppressing cell filamentation and ability to support the multiplication of phage P22 in Salmonella typhimurium. Acta biochemica polonica 26 , 135-143.

KuSHNER, S. R. (1978). An improved method for transformation of Escherichia coli with ColE1 derived plasmid. In Proceedings of International Symposium on Genetic Engineering, pp. 17-23. Edited by H. W. Boyer \& S. Ricosia. Amsterdam: Elsevier/ North Holland Biomedical Press.

LederberG, E. M. \& CoHEN, S. N. (1974). Transformation of Salmonella typhimurium by plasmid deoxyribonucleic acid. Journal of Bacteriology 119, 1072-1074.

Maclachlan, P. R. \& Sanderson, K. E. (1985). Transformation of Salmonella typhimurium with plasmid DNA: differences between rough and smooth strains. Journal of Bacteriology 161, 442-445.

Mandel, M. \& HigA, A. (1970). Calcium-dependent bacteriophage DNA infection. Journal of Molecular Biology 53, 159-162.

Maniatis, T., Fritsch, E. F. \& SAMbroOK, J. (1982). In Molecular Cloning: a Laboratory Manual. Cold Spring Harbor, NY: Cold Spring Harbor Laboratory.

Matsushima, P., Cox, K. L. \& Balts, R. H. (1987). Highly transformable mutants of Streptomyces fradiae defective in several restriction systems. Molecular and General Genetics 206, 393-400.

Merrick, M. J., Gibbins, J. R. \& Postgate, J. R. (1987). A rapid and efficient method for plasmid transformation of Klebsiella pneumoniae and Escherichia coli. Journal of General Microbiology 133, 2053-2057.

Mizuno, T., Mutoh, N., Panasenko, S. M. \& Imae, Y. (1986). Acquisition of maltose chemotaxis in Salmonella typhimurium by the introduction of the Escherichia coli chemosensory transducer gene. Journal of Bacteriology 165, 890-895.

Nagaraja, V., Shepherd, J. C. W., Pripfl, T. \& BICKLE, T. A. (1985). Two type I restriction enzymes from Salmonella species: purification and DNA recognition sequences. Journal of Molecular Biology 182, 579-587.

Norgard, M. V., Keem, K. \& Monahan, J. J. (1978). Factors affecting the transformation of Escherichia coli strain $\chi 1776$ by pBR322 plasmid DNA. Gene 3, 279-292.

OISHI, M. \& IRBE, R. M. (1977). Circular chromosomes 
and genetic transformation in Escherichia coli. In Modern Trends in Bacterial Transformation and Transfection, pp. 121-134. Edited by A. Portoles, R. Lopez \& M. Espinosa. Amsterdam: North-Holland Publishing Co.

Sanderson, K. E. \& Hurley, J. A. (1987). Linkage map of Salmonella typhimurium. In Escherichia coli and Salmonella typhimurium: Cellular and Molecular Biology, vol 2, pp. 877-918. Edited by F. C. Neidhardt and others. Washington, DC: American Society for Microbiology.

SANDERson, K. E. \& Stocker, B. A. D. (1987).
Salmonella typhimurium strains used in genetic analysis. In Escherichia coli and Salmonella typhimurium: Cellular and Molecular Biology, vol 2, pp. 12201224. Edited by F. C. Neidhardt and others. Washington, DC: American Society for Microbiology.

SAUnders, V. A. \& SAUnders, J. R. (1987). In Microbial Genetics Applied to Biotechnology. Principles and Techniques of Gene Transfer and Manipulation, pp. 3-20. New York: Macmillan Publishing Company. 